\title{
Brachial Lymph Node
}

National Cancer Institute

\section{Source}

National Cancer Institute. Brachial Lymph Node. NCI Thesaurus. Code C92221.

An axillary lymph node along the brachial vein. 